\title{
SOME PARTICULAR ASPECTS OF THE LEGAL STATUS OF LOCAL ADMINISTRATION IN THE ROMANIAN AND FRENCH CONSTITUTION E. Sferlea
}

\author{
Elena Sferlea \\ PhD. in Law, Paris XII University \\ Assistant Professor, Agora University of Oradea \\ ileanamarcu@gmail.com
}

\begin{abstract}
:
Part of a wider comparative research focused on the evolution of local government in Romania and France during the last twenty years and, in particular, on the progress made by the two countries in their common way towards decentralization, this study takes into account the relatively recent changes in the Constitution relating to local law and wants to emphasize the sometimes different approaches of legislators as reflected in the specifics of constitutional status in each country, especially the coordinating role assigned to the County Council, under Romanian law, and to the Senate as a national forum of local communities, under French law.
\end{abstract}

Key words: local government, Constitution, local authority, decentralization, County Council, Senate, local status, territorial communities

\section{Introduction}

The main differences between the legal status of local administration in the two countries relate to the specific coordination tasks assigned to the County Council and the use of the languages of national minorities in public administration, in the Romanian Constitution, and the significant presence of the overseas territories, in the French Constitution. The European issue and that relating to the representation of local communities in the French Senate can also be treated as particular elements in the Constitution. This comparative study will provide a brief presentation of the special role given in the Constitution to the County Council, under Romanian law, and to the Senate, under French law.

\section{The coordinating role of the romanian county council}

The two paragraphs of article 122 of the Romanian Constitution are devoted to the County Council (the so-called "Județ"). The origin of the departmental (county) system in Romania dates back to the 1923 Constitution and the Law on Administrative Unification of 1925. It was maintained until 1938, when the so-called "Ținuturi" were created, which were larger territorial areas than the counties. This was the beginning of a period marked by a lack of local autonomy that the creation of the Regions in 1950 would perpetuate until $1968^{1}$. Currently, the Romanian County is the single intermediate authority between the local authority and national government, unlike the administrative organization of France which has three territorial levels. As for the local authority, the County provides a framework for both decentralization and devolved administration ${ }^{2}$.

1 A. Iorgovan in M. Constantinescu, A. Iorgovan, I. Muraru, E.S. Tănăsescu, Constituţia României revizuită comentarii şi explicaţii - (The revised Constitution of Romania - comments and explanations -), All Beck, Bucharest, 2004, pp. 258-259.

2 In French «administration déconcentrée». 
The common tradition with France on administrative control and the choice of a twolevel territorial administration explains the choice in the Romanian legislators of 1991 to empower local authorities and towns and to limit the involvement of the County to a coordinating role (art. 122 para. 1 of the Constitution). The County Council becomes the arm "of the public administration" charged with "coordinating the activities of local and town councils." The objective set is "the achievement of public services in the interests of the County." This coordinating role is reiterated in the Law on Local Government no. 215/2001 as amended in article 87 paragraph 1.

It is generally considered that the arrangements for coordination of the activities of local and town councils, underpinning the County Council in Romanian law, is solely the implementation of public services in the interests of the County and expresses the intention of the legislators to increase the autonomy of the local authority ${ }^{3}$. This provision of the Constitution is also criticized in theoretical literature because it "preserves only one aspect of the powers of County Councils" while "in reality, the County Councils also have other powers"4. At the same time, legal literature includes this aspect in the category of the specific powers of County Councils ${ }^{5}$. A clarification comes in the amendments made by Law no. 286/2006. According to the new art. 101 para. 1 of the Law no. $215 / 2001$ (art. 87 para. 1 following publication of the new Law in 2008), the coordinating role is the general element that defines the County Council as the authority organized at county level and not a separate category of responsibilities among the five listed in the amended article 104 para. 1 of the General Law on Local Government (corresponding to the current article 91 para. 1 which now includes six categories ${ }^{6}$ of responsibilities). It is therefore possible to say that the legislators have proceeded to align the law with the Constitution. Under the new article 104 para. 5, section d) of the above Law, the County Council shall offer, upon request, technical assistance to the communities in the County. This provision is part of those duties pertaining to management of those public services for which it is responsible (art. 104 para. 1, section d). Even if they were renumbered following the publication of the new Law no. 215/2001 in 2008, we find these almost identical provisions, in the current text, article 91 para. 1, section d) and para. 5, section d). The County Council is made responsible for and must provide, upon request, its advice in specific areas, for the benefit of the communities in the County "as stipulated by law."

If we compare the exclusive powers of local authorities and towns set out in the Law of Decentralization no. 195/2006 (article 21 sections a) -m)), on the one hand, and those assigned to the County (art. 22 sections a) -g) of the same law), on the other hand, the preference of the Romanian legislator for the local authority is plain to see. According to the same text, this priority can also be seen in the case of the aportionment of competences with central government, where significantly more powers are devolved to local authorities and towns (article 24 sections a) $-\mathrm{k}$ ) of the Law no. 195/2006) than to the Counties (art. 26 sections a) -g)). This confirms the intention of the legislators as derived from article 122 of the Constitution.

Succinctly written, the second paragraph of article 122 stipulates that the County Council is an "elected" authority that "operates under conditions stipulated by law." As formulated, the drafter of the Constitution once again shows a flexible approach and allows

3 C. Manda Manda C.C., Dreptul colectivităţilor locale (The law of local communities), 2nd revised and supplemented ed., Lumina Lex, Bucharest, 2005, p. 173.

4 D. Brezoianu, Drept administrativ român (Romanian administrative law), All Beck, Bucharest, 2004, pp. 414-415.

5 R.N. Petrescu, Drept administrativ (Administrative law), Accent, Cluj-Napoca, 2004, p. 209.

6 The last category relates to the general heading of "other duties stipulated by the law" (art. 91 para. 1, section f)). 
the legislator to determine, at the County level, direct or indirect elections, as well as to establish one or more executive authorities. As regards the local authorities, the principle of holding elections is a constitutional guarantee for the existence of the County Council. In the absence of any express provision in article 122, the correlation with the new para. 4 of article 123 of the Constitution makes clear that the President of the County Council is also a constitutionally protected ${ }^{7}$ body.

Like in France, Romanian county councillors ${ }^{8}$ are directly elected. If, in the case of France, their constituency is the so-called "canton", in Romania it is at County level (art. 10 para. 2 of the Law on Election of Local Government no. 67/2004). The duration of their mandate also varies : 6 years in France and only 4 years in Romania. The number of VicePresidents is between 4-15 in the French case, provided that their number does not exceed $30 \%$ of the total number of councillors, while the Romanian County Council has only 2 VicePresidents (art. 101 para. 1 of Law no. 215/2001 as amended). Despite its coordinating role, the Romanian County Council remains an autonomous administration, which excludes any form of subordination in its relations with any other local authority. The lack of hierarchy and the cooperation between local authorities are characteristics of the legal status of local administration as reflected in the Romanian Constitution?.

\section{The french senate, representative of territorial communities}

In addition to the great diversity that characterizes the institutional nature of the French overseas and dependent territories, one should also include the enhanced role of the Senate in representing all the territorial units of the Republic, under the new article 39 of the Constitution. Henceforth Bills whose main purpose concerns territorial ${ }^{10}$ organization are submitted firstly to the Senate, which has simply been the formalisation of an already existing practice. Through its constitutional and legislative oversight ${ }^{11}$ and the exercise of its control ${ }^{12}$ functions, the French Senate has contributed to the development of a better defined legal framework for local government. To strengthen the dialogue ${ }^{13}$ between the actors of decentralization, the Senate has also developped an information channe $1^{14}$ for the local actors.

Unlike French senators who are appointed by indirect universal suffrage through an electoral college organized in each County, for a term of 6 years, Romanian Senators are directly elected for 4 years (articles 62 para. 1 and 63 para. 1 of the Constitution). At the same time, in accordance with article 75 para. 1 of the Romanian Constitution, Bills concerning the

7 In this sense see Iorgovan A. Constantinescu, A. Iorgovan, I. Muraru, ES Tănăsescu, op. cit., pp. 259-260.

8 The very recent Law no. 2013-403 (17 May 2013) renamed the French county councillors ("conseillers généraux") as "departmental councillors" ("conseillers départementaux"). Their next election will take place in 2015.

9 C. Manda, C. C. Manda, op. cit., p. 174.

10 One should note some difficulties of interpretation of the purpose of these Bills.

11 Apart from discussion of the texts submitted to it, the French Senate, as the advocate of local liberty, led the Constitutional Council to rule on several occasions for local authorities. It is also important to add that the constitutional reform of 2003 introduced into the fundamental Law a few principles which the Senate had been defending for a long time for the benefit of the local communities.

12 These consist of senatorial fact-finding visits, study groups, information reports, classic written and oral classic questions with or without debate, as well as a Senate Committee for decentralization. Composed of 25 senators, it has been operating as a network since January 19, 2005. In April 2009, a Senatorial Delegation for territorial communities and decentralization was created.

13 In December 2011, the President of the Senate decided to organize the so-called "Etats généraux de la démocratie territoriale" in order to learn the expectations and proposals of the "élus" about the future of their communities.

14 The French Senate organizes various events and meetings such as "Citizens of local elected officials", and since 1998 it has at its disposal a Local Authorities Service and, since February 1999, a Permanent Forum for exchange and information, "Crossroads of local authorities" (http://carrefourlocal.senat.fr). 
organization of local government, territorial organization and the general arrangements for local autonomy (art. 73 para. 3, section o)), on administrative disputes (art. 73 para. 3, section $\mathrm{k})$ ) and on use of the mother tongue of minorities in relations with local authorities and devolved services (art. 120 para. 2) must first be presented to the Chamber of Deputies. In Romanian law, the Chamber of Deputies is the decisional body. Apart from matters expressly stipulated in the constitutional provisions mentioned above, other Bills or legislative proposals are submitted first to the Senate. A role reversal can be seen between the Chambers of Parliament in comparison with the French case.

In France, a senator is the representative of the Nation. According to the Declaration of the Rights of Man and of the Citizen (art. 3), a senator does not represent his district, but the Nation itself. At the political level only, he is also the representative of the County where he was elected by the so-called "big electors"15. The method of electing French senators leads to a strong representation of territories because they are elected by local politicians, especially those in charge of local administration. The multiple mandate ${ }^{16}$ system permits the vast majority of French senators to carry out a local elective mandate ${ }^{17}$, which keeps them in direct contact with local issues. During their mandate, members of the Romanian Senate "serve the people" (art. 69 para. 1 of the Constitution) and their function "is incompatible with the exercise of any civic authority, apart from that of a member of the Government " (art. 71 para. 2 of the Constitution).

It is significant to note that the second paragraph of article 62 of the Romanian Constitution guarantees the right of organizations belonging to national minorities to be represented in Parliament. Thus, minority organizations which do not obtain the number of votes necessary for parliamentary representation each have, under the conditions stipulated by the electoral law, a parliamentary seat. Citizens of a minority cannot be represented by a single organization. Considered a measure of "positive discrimination" which brings "uniqueness" to the Romanian constitutional system, this provision is justified by the protection of the right to identity stipulated in article 6 para. 1 of Constitution ${ }^{18}$.

\section{Conclusion}

These two particular aspects of the legal status of local administration emphasize a different choice of the legislators in the countries studied. The Constitution assigns a coordinating role to the County Council mainly explained by the specific historical evolution of the County in the administrative organization of Romania. It is also important to mention that the office of President of the County Council has been directly elected since 2008 . Coordination is limited to the activity of the local councils and the purpose is only to provide high quality services at the County level. Thus the main objective of the legislator is to

15 There are approximately 150,000 "big electors" who are required to participate in the vote. This college is composed of deputies, regional counsellors, councillors of the Corsican Assembly, county councillors, councillors of the city of Paris as well as delegates of local councils whose number is based on the population in their area. It is a system that leads to a strong representation of rural communities within the college. As $95 \%$ of Senate delegates represent the local councils, the Senate is the Grand Council of Municipalities of France.

16 Two very recent laws (published in the Official Journal the $16^{\text {th }}$ of February 2014) prohibit multiple mandate of French Senators. Despite their opposition, these provisions will be applied for the first time after the elections of March 2017.

17 As of 24 September 2007, 79.75\% of French Senators were serving at least one local mandate (www.senat.fr). It is interesting to note that the Socialist Party wants to ban its senators from holding an extra mandate in a local authority, an idea confirmed by party activists in a referendum of 1 October 2009. Despite the hostility of its senators to the measure, the rule prohibiting multiple mandate would have immediate effect. Senators whose mandate was to be renewed in 2011 could retain their positions in the local authorities for a further year, to organize a successor. In 2011, the French Senate was composed of 348 senators.

18 M. Constantinescu in M. Constantinescu, A. Iorgovan, I. Muraru, E. S. Tănăsescu, op. cit., p. 120. 
strengthen the autonomy of the local authorities. In the French example, multiple mandates and the particular way in which senators are elected explains how territorial communities are represented in the Senate. The French Senate offers territorial communities the opportunity to be directly protected at national level, in the legislative arena. In this way, Senators can promote local interests through their various parliamentary activities. In both cases, local communities benefit from constitutional protection and can make a major contribution to the development of local government law.

\section{Bibliography}

1. Brezoianu D., Drept administrativ român (Romanian administrative law), All Beck, Bucharest, 2004

2. Constantinescu M., Iorgovan A., Muraru I., Tănăsescu E.S., Constituţia României revizuită - comentarii şi explicaţii - (The revised Constitution of Romania - comments and explanations -), All Beck, Bucharest, 2004

3. Manda C., Manda C.C., Dreptul colectivităţilor locale (The law of local communities), 2nd revised and supplemented ed., Lumina Lex, Bucharest, 2005

4. Petrescu R.N., Drept administrativ (Administrative law), Accent, Cluj-Napoca, 2004

5. The Constitution of France

6. The Constitution of Romania

7. The official web site of the French Senate, www.senat.fr

8. The official web site of the Romanian Chamber of Deputies, www.cdep.ro 